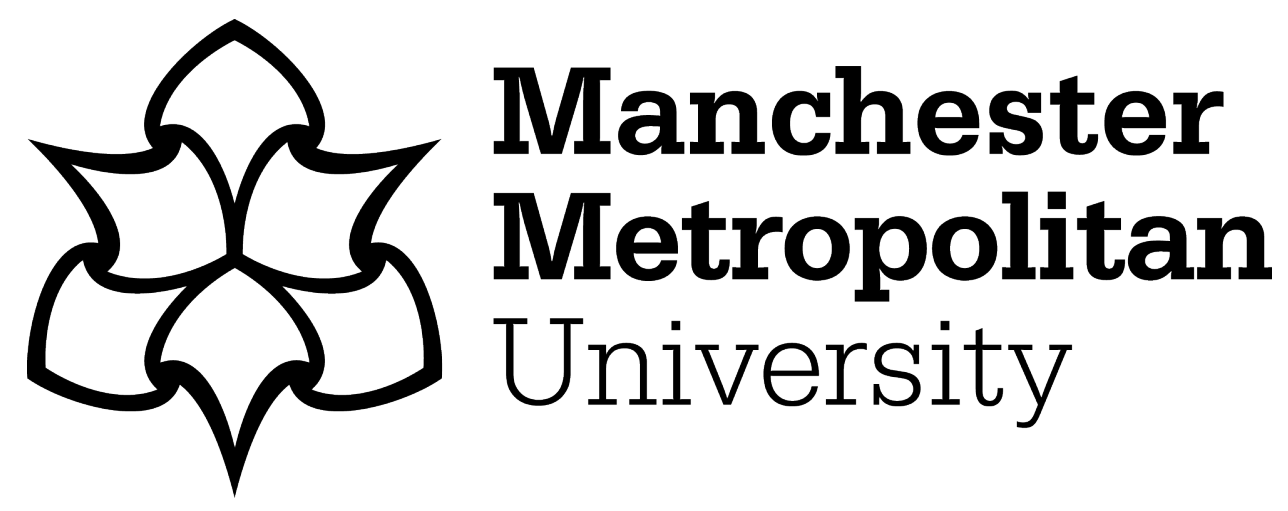

Walker, J, Ashby, J ORCID logoORCID: https://orcid.org/0000-0001-71102635, Gredecki, N and Tarpey, E ORCID logoORCID: https://orcid.org/00000003-2238-2719 (2017) Gender representations of female perpetrators of intimate partner violence. Journal of Aggression, Conflict and Peace Research, 10 (3). pp. 170-180. ISSN 1759-6599

Downloaded from: https://e-space.mmu.ac.uk/620741/

Version: Accepted Version

Publisher: Emerald

DOI: https://doi.org/10.1108/JACPR-02-2017-0273

Please cite the published version 


\title{
Gender representations of female perpetrators of intimate partner violence
}

\author{
Jenna Walker, Jo Ashby, Neil Gredecki and Emma Tarpey
}

\author{
Jenna Walker is a Forensic \\ Psychologist at HMP \\ Dovegate, Uttoxeter, UK. \\ Jo Ashby is a Senior Lecturer in \\ Psychology at the Department \\ of Psychology, Manchester \\ Metropolitan University, \\ Manchester, UK. \\ Neil Gredecki is a Regional \\ Lead Psychologist for HM \\ Prison and Probation Service, \\ and a Clinical Lecturer at the \\ University of Manchester, \\ Manchester, UK. \\ Emma Tarpey is a Senior \\ Lecturer at the Department of \\ Psychology, Manchester \\ Metropolitan University, \\ Manchester, UK.
}

\begin{abstract}
Purpose - The purpose of this paper is to understand the constructions of female-perpetrated intimate partner violence (IPV) among postgraduate (PG) students studying and preparing for a career in forensic psychology. A social constructionist methodological framework was adopted in order to explore students' dominant discourses surrounding gender and IPV. Of particular interest was how female perpetrators of IPV within heterosexual relationships were constructed and subsequently positioned by students in terms of social and gender identity. Implications regarding future practice for graduates in relation to risk assessment and treatment interventions are discussed.

Design/methodology/approach - Six female PG forensic students took part in a qualitative focus group and discussed their understanding of IPV and views regarding perpetration. Focus group members were also asked to discuss details of a vignette depicting a violent relationship where gender identity was purposefully removed. The focus group interview data were analysed using Foucauldian discourse analysis.

Findings - The students constructed IPV as a behaviour that was predominantly perpetrated by men towards women. Students acknowledged that female-perpetrated IPV occurred; however, such behaviour was constructed as non-threatening, and subsequently, less serious than male-perpetrated IPV. Moreover, the analysis revealed that the overall discourses drawn on by the students projected a feminine representation of female IPV that positioned women as emotionally unstable, vulnerable and acting in self-defence.

Research limitations/implications - Students' constructions of female-perpetrated IPV appeared to minimise aggression. It is argued that the positioning of women in terms of vulnerability serves to undermine any responsibility for perpetrating violence among this group of students. In terms of implications for practice, oversimplified assumptions in relation to gendered constructions have the potential to inhibit female IPV from being recognised as a serious form of aggression, and it is argued that this could potentially bias assessments of risk leading to an under-estimation of threat. Female perpetrators of IPV may subsequently receive inadequate supervision and intervention and inadequate levels of victim safety planning may occur. These gendered constructions may also inhibit male victims from seeking help and help being offered.

Originality/value - This paper highlights the importance of understanding constructions of IPV among students who are preparing for careers as a forensic psychology practitioner. Female IPV is clearly challenging. With respect to the social construction of IPV, the students in this study made many assumptions about female identity by linking this to feminine and essentialist ideas that constrain women as emotionally and biologically vulnerable. Such findings raise questions about whether future training and study programmes are equipped to critically challenge the dominant discourses and subsequent constructions of gender and IPV. Thus, this study has highlighted the need for further research around constructions of IPV in this field of work in order to fully examine potential knowledge gaps in training and teaching of future forensic practitioners.
\end{abstract}

Keywords Gender, Identity, Intimate partner violence, Positioning, Foucauldian discourse analysis, Social constructions

Paper type Research paper

\section{Introduction}

Intimate partner violence (IPV) is often widely constructed as an offence perpetrated by men towards women (Dutton and White, 2013). Statistics from the Office for National Statistics (2015) showed that in 2013/2014, 6.8 per cent of women (aged 16-59) experienced IPV within the past year, and 28.3 per cent within their lifetime. Within the same period, 3 per cent of adult men reported experiencing aggression from a current or ex-partner within the previous year,
Received 20 February 2017 Revised 28 May 2017

Accepted 12 June 2017 
and 14.7 per cent within their lifetime. Whilst figures are lower for men reporting IPV victimisation, there is evidence to indicate under-reporting (Dutton and White, 2013), which is a trend also observed in other types of female offending (see Cortoni et al., 2017 for a review of female sexual offending).

One explanation suggests that social constructions of gender inhibit men from labelling their experiences as abuse (Desmarais et al., 2012; Povey et al., 2009) in order to avoid embarrassment and maintain a masculine identity (Hogan, 2016). Gendered social constructions have also featured predominantly in the treatment of IPV, with models for understanding its aetiology being historically dominated by ideas of women's oppression believed to have resulted from patriarchal influences (Dobash and Dobash, 1979, 2004), and feminist narratives of male privilege, power and control (Duluth Model: Pence and Paymar, 1993). Indeed, violence perpetrated by women has often been viewed within the context of victimisation and self-defence, particularly in response to provocation by abusive men (Swan and Snow, 2006). However, research suggests that women's violence functions primarily to manage negative emotions, gain revenge and to gain their partner's attention (Leisring, 2013). Increasingly, research has found equal or higher rates of IPV perpetrated by women within heterosexual relationships (Archer, 2000, 2006), with women continuing to perpetrate physical and sexual aggression within the context of IPV (Williams et al., 2008). Studies show that women are more likely to engage in emotional abuse (Graham-Kevan and Archer, 2009; Hines and Douglas, 2010), demonstrating behaviours that are considered to be coercive and controlling (Home Office, 2013).

Despite empirical evidence of women's use of aggression, social constructions of gender and identity (Butler, 1990; Lorber, 1994, 2010) present challenges when acknowledging female-perpetrated IPV. Indeed, women have historically tended to be portrayed as victims of IPV (Tsui, 2014). Moreover, according to Sorenson and Taylor (2005), female-perpetrated IPV is viewed as less serious compared to violence perpetrated by men, with the effects being minimised. Research has demonstrated that women are considered to be less dangerous than men and to pose less threat to others (Elbogen et al., 2001; Ulmer and Kramer, 1996). These "essentialist" views of female gender roles are based on "femininity" (see Bem, 1993) that position women in terms of their physical size and strength, and in turn can be influential when considering perceptions of risk and harm (Hamby and Jackson, 2010). Associating physical size with threat is problematic, especially as physical strength is not causally related to IPV (Graham-Kevan and Ashton Wigman, 2009) and thus highlights how inaccurate social constructions of female-perpetrated IPV can be. Similarly, research has shown that despite public assumptions that female offending is increasing, female-perpetrated violence has actually remained stable over time; according to Kruttschnitt et al. (2008), this reflects gendered constructions of how female behaviour is portrayed.

Indeed, more recent research indicates that female- and male-perpetrated IPV have similar underpinning risk factors and motivations (Elmquist et al., 2016; Thornton et al., 2016); including the presence of offence supportive beliefs about violence (Simmons et al., 2008), emotion dysregulation and poor emotional management (McNulty and Hellmuth, 2008).

Despite both the increasing recognition of the empirically derived risk factors related to female-perpetrated IPV and the prevalence rates, social discourse continues to position women in ways that minimise their aggression (Sjoberg, 2010). Research suggests that gender identity is an important consideration in both the perpetration of IPV and victimisation (Connell, 2002; Schrock and Padavic, 2007). According to Butler (1990) and Oyserman et al. (2012), gender and identity stereotypes are created through language, which people look to in order to define and attach meaning to their own masculinity or femininity. Connell's (2002) work encourages consideration of how gender ideals reflect "hegemonic masculinity" and "emphasised femininity" with the former valuing strength and honour in men; and the latter valuing vulnerability, compliance and subordination by women (Connell, 2002; Connell and Messerschmidt, 2005). Hence, constructions of femininity portray expectations of subjugation, which readily position women as victims (see Hearn, 2013; Schippers, 2007). Harré and Moghaddam (2003) emphasise that the positioning of men and women in this way affords certain rights associated with the expectations of these roles during social interactions. Furthermore, Harré and van Langenhove (1999) argue that discourse and positioning determine individual and collective identities, 
with dominant societal groups consequentially holding greater privileges and entitlements, which are upheld through discursive practices. In relation to gender identity, positioning therefore has important implications relating to power dynamics by legitimising certain actions and behaviours (Davies and Harré, 1990; van Langenhove and Harré, 1999; Harré and Moghaddam, 2003).

Research exploring the positioning of women within social interactions and wider society in relation to IPV suggests that gender identity features prominently in explanations of female-perpetrated IPV. According to Swan and Snow (2006), women's aggression is primarily framed within a "fear-driven" psychological discourse, often being considered as an understandable response to provocation or coercion by men (Sjoberg, 2010). This is in contrast to research indicating that in some instances women are the sole perpetrators of IPV (Steward et al., 2014), even in the absence of mutual relationship violence (Dutton and White, 2013). Yet these gendered discourses around women's aggression reflect normative stereotypes with narratives emphasising women's innocence, vulnerability and peacefulness (see Sjoberg, 2010). Positioning women in terms of emphasised femininity (Connell, 2002) seemingly goes some way in understanding peoples' reluctance to view women as the primary aggressor. Such constructions of femininity may in fact function to justify women's violence by portraying it as an act against repression (Sjoberg, 2010).

Female-perpetrated aggression therefore deviates from notions of femininity, which challenge essentialist views; subsequently, people are less likely to view violent behaviours by women as aggressive (Heyman and Giles, 2006). Furthermore, where female-perpetrated violence is acknowledged, it is often constructed within a medical discourse of mental ill health and pathology, or sexual deviance (Sjoberg and Gentry, 2008; Carlyle et al., 2014). This is particularly the case following serious physical assaults (Berrington and Honkatukia, 2002) and homicide (Ashley, 2008). As such, according to Noh et al. (2010), social constructions of women's violence alleviate responsibility. In addition, Sjoberg (2010) suggests that these constructions are problematic in that they maintain gender inequality and obscure the underlying reasons why female-perpetrated violence occurs. Thus, a critical analysis of gendered views in relation to IPV may begin to provide valuable insight into understanding practitioners' approaches to the complexity of female IPV and how this is subsequently managed within a forensic setting.

It is argued that social constructions of gender have significant implications for victims, as well as female perpetrators of IPV. Indeed, Laroche (2005) found that abused men were often excluded from services that tended to focus on women's victimisation needs. Furthermore, gendered expectations within relationships, specifically hegemonic masculinity and emphasised femininity, were found to be an inhibiting factor in terms of help-seeking behaviours amongst male victims. This is despite the significant adverse effects of female-perpetrated IPV upon the physical and psychological wellbeing of male victims (see Hogan, 2016).

Further implications of gendered constructions upon forensic practice are concerned with assessments of need and risk. Risk assessment tools (e.g. HCR-20v3: Douglas et al., 2013; B-SAFER: Kropp et al., 2005) and the underpinning research regarding the assessment of aggression are based upon a gender-neutral literature base (Tremblay et al., 2005). Estimations of risk and the identification of treatment needs among male and female perpetrators of IPV are, however, recognised as being subject to biases (Coontz et al., 1994; McNeil and Binder, 1995; Skeem et al., 2005; Ulmer and Kramer, 1996). Moreover, perceptions of IPV can be problematic particularly when there are differences between these perceptions and realities. This poses significant challenges for forensic practitioners and for those tasked with designing IPV programmes, as without a sound understanding of how influential perceptions can be, IPV perpetration cannot be effectively addressed (Whitaker, 2014). Therefore gendered constructions of female-perpetrated IPV have important implications both when assessing and meeting the needs of victims, and perpetrators. Social constructions of female-perpetrated IPV raise important questions about how a gender-neutral approach is achieved in practice, particularly amongst practitioners and those preparing for a career in forensic psychology, and how social constructions are challenged as part of their training.

Training in forensic psychology in the UK broadly consists of three distinct stages: Stage 1 - completion of an accredited master's degree in forensic psychology; Stage 2 - supervised practice under the direction of a registered (qualified) forensic psychologist; and Stage 3 - post-qualification professional development training. Given the 
breadth of training opportunities for those working in the field of forensic psychology, this study strived to explore the discursive constructions of female-perpetrated IPV within a cohort of participants engaging in Stage 1-level training. The exploratory nature of the research sought to better understand discursive constructions of female-perpetrated IPV and to give some consideration as to whether such discourses are evident at this level of training.

\section{Research aims}

The current research aimed to explore and understand the constructions of female-perpetrated IPV amongst postgraduate students seeking a career as a forensic practitioner. A social constructionist approach was adopted to explore dominant discourses that surround gender and IPV. Of particular interest was how female perpetrators of IPV within heterosexual relationships were positioned in terms of their social and gender identity, as well as the possible implications of these discourses upon risk assessment and treatment interventions. A qualitative design was employed as this methodology was consistent with the aims, albeit to understand meaning rather than empirical "truths".

\section{Method}

The lead author conducted a focus group with six female students engaging in Stage 1 of forensic psychology training who were from different ethnic backgrounds. Both male and female students were invited to take part in the research; however, no male participants attended. Ethical approval was granted through the university where participants were studying. The focus group followed the process outlined by Litosseliti (2007), including establishing group rules and issues of confidentiality, before progressing through the focus group schedule. Students were asked a series of questions regarding their understanding of IPV and their views of perpetrators. They also collectively discussed a gender-neutral vignette (see Box 1) that was designed for the research and which depicted an escalation in IPV. Students were provided with opportunities to discuss issues they believed were pertinent. The character's name in the vignette was purposefully selected because it was gender-neutral, which facilitated further discussion regarding perceptions of risk of violence and harm to others. Students were not asked about personal experiences of IPV and were not encouraged to discuss personal issues during the focus group session.

The session was audio recorded and transcription was based on the Jefferson Lite system (see Parker, 2005). This was sufficient for the purposes of the current research and some non-verbal characteristics were retained, including pauses. The length of pause within the transcripts are represented by (.) for one-second pause (..) two seconds and so on. Analysis followed the stages outlined by Willig (2013) in relation to Foucauldian discourse analysis (FDA). FDA was identified as appropriate, particularly because of the emphasis on power, which is argued to be relevant to studies of gender (Willig, 2013).

\section{Analysis and discussion}

The analysis presents the students' social constructions of female-perpetrated IPV. The discussion that was facilitated during the focus group enabled students to talk about female-perpetrated IPV by initially focusing on their understanding of associated behaviours

\section{Box 1: Vignette}

Until recently, Sam lived at home with their partner and young baby. The relationship has always been volatile and in recent months, and following the birth of their child, it has become worse. The arguing often escalates and Sam has used violence, hitting their partner on a number of occasions. The police have been to the house three times in the past year. Each time this has been because the neighbours have called 999, after hearing Sam shouting. Sam has been arrested again recently and has been staying at a friend's house temporarily, but now wants to come home. 
before progressing to explanations of IPV occurrence and wider considerations. It is not possible to discuss all of the constructions that were evident in the analysis due to word limitations. Therefore, what is presented in the following section focuses specifically on discourses deemed most relevant to the research aims and how they link to implications for forensic practice.

During the focus group, students consistently constructed female-perpetrated IPV as being a form of behaviour that is in general, not taken as seriously as violence perpetrated by men. Students drew on gendered discourses in order to make comparisons between men and women's behaviour. For example, one student said:

Like women might not be like (.) you know like when men get violent (.) well (.) maybe not always where you know think punching or something like that (.) a woman might be just like (.) a little slap but it's constant or something like that I think they are more violent just in little (.) little ways [...] so it's brushed under the carpet.

It is clear from the above excerpt that this student viewed female IPV as very different to male-perpetrated IPV. Although she described women as "more violent", the violence itself was characterised as "little" and unseen, "brushed under the carpet". In this way, female perpetrators were not positioned as physically violent partners, rather as enduring, yet minimal: "just like a little slap". In contrast, male-perpetrated violence was perceived in terms of immediate physicality "punching", implying potential for more serious harm. Such discursive practices indicate broader cultural expectations associated with identified gender roles in that, for women, there is potential for aggressive acts to be misinterpreted as less harmful. Female-perpetrated IPV being "brushed under the carpet" we suggest serves to uphold dominant rights and privileges. For example, the positioning of male perpetrators of IPV and recognition of the seriousness of such behaviour reflect wider institutional practices associated with the subjugation of women (Connell, 2002) that secure the power of men over women. We argue that this has important implications for practice, particularly as gendered constructions, similar to this example, could be one explanation for the lack of recognition of the seriousness of female-perpetrated IPV.

It has been widely documented how women are positioned as much less dangerous than men (Coontz et al., 1994; McNeil and Binder, 1995; Skeem et al., 2005; Scarduzio et al., 2017) and thus less threatening. Many of the students drew on notions of physical differences in terms of size and strength between men and women in order to construct the potential risks for harm as much higher for men than women. When asked to consider the risk of a perpetrator returning home following an incident of IPV, one student responded by saying:

If it was umm the woman was coming back to the man umm a lot of the community neighbour's friends and family would be like no don't go back whereas if it was the other way round maybe the community would have a different view point like oh you know take her (.) back you know she's the mother of your child that sort of thing (..) they don't see (.) perceive the threat.

Here the woman's role as a mother is specifically considered in order to assess the potential for further violence. Women are viewed as natural caregivers and the student's response can be understood within an essentialist framework, where any suggestion of serious violence to their partner is incongruent with the role of a mother. Subsequently, students in this study appeared to resist positioning women as violent, and instead positioned them as carers, and thus consistent with expected social and cultural practices afforded to this role. Framing women's identity in this way appeared to minimise the perception of risk for communities and families. One explanation suggests that essentialist views are reductionist and act to maintain gender inequality by overly focusing on women's biological roles (Bem, 1993). Constructing female perpetrators of IPV in this way has important implications, particularly as the needs of victim's/potential victims may not be fully recognised: "they don't see [...] the threat".

Moreover, positioning women in terms of biology consequently implies a lack of agency; as such, gendered constructions uphold wider social institutions in relation to female oppression (Connell, 2002; Connell and Messerschmidt, 2005). The students' reasoning in an essentialist way was further evident when discussing emotionality and female-perpetrated IPV:

Women are always viewed as sort of hysterical all the time making a big deal out of every little thing so what (..) you express jealousy or things like that or go psycho bitch it's nothing because it's just typical of women [...]. And then there's the hormones. 
This student's account reflects many of the essentialist arguments that have been used in order to point out women's deficiencies, even if in this case, it is their ability to carry out IPV against a male partner. Heyman and Giles (2006) argues that essentialist reasoning is a "theory of limits" in that it can influence the range of choices people consider for themselves and others. Furthermore, if gender roles reflect innate, natural tendencies, people are less likely to consider, or indeed comprehend behaviours outside these roles such as violence and aggression perpetrated by women. In this study it was evident that female perpetrators of violence were framed and positioned within traditional notions of femininity in terms of emotional instability and "hormones". One explanation suggests that in seeking to understand behaviour that differs markedly from existing gender norms, people draw upon other dominant discourses, which for violent women includes pathology and mental/emotional instability (Sjoberg and Gentry, 2008); all of which, however, perpetuate female-perpetrated IPV as being understood within an essentialist and thus limited gendered framework.

Without this positioning, female-perpetrated IPV would not be legitimised due to increased accountability. Therefore, within the current study, essentialist constructions functioned to enable female-perpetrated IPV to continue whilst facilitating social acceptance and tolerance. Many of the student's responses also described help seeking by male victims within an essentialist framework. During their discussion, students identified how social influences may inhibit help seeking, particularly in terms of maintaining masculine identities consistent with physical and emotional invulnerability (Connell, 2002). Although male victimisation was acknowledged, men were not positioned as vulnerable. Instead, many responses constructed male victimisation as something that would be laughed at:

He might think he'll get laughed at (.) you know like that's a woman why can't you just stop her? You should be stronger than her.

Within this construction the student draws upon a biological essentialist discourse. Here, the man is not positioned as helpless; rather the expectation is that he would be ridiculed because he would not be physically strong enough to stop female-perpetrated violence. Within this construction, men were assumed to have an active role with a position of dominance, rather than passivity. The expectation afforded to this position is one of responsibility for stopping the aggression. The female-perpetrated IPV is thus constructed as non-threatening and humorous rather than something potentially serious for a man to experience.

Perceiving male victimisation in this way has important implications, however, for subjectivity. In drawing upon gender norms and stereotypes, people make assumptions about the thoughts, feelings and experiences of others within that collective group (van Langenhove and Harré, 1999). The practices associated with masculinity assert expectations of emotional infallibility (Connell, 2002); therefore, any distress resulting from female-perpetrated IPV is invalidated.

Many of the students also identified the difference in response that male victims may receive if they were to disclose such an experience:

Why are we laughing when it's violence between (.) when it's a woman being violent towards a man but you know we're taking it very seriously when it's a man abusing a woman?

In drawing upon gendered discourse, humour further functioned to minimise the potential detrimental effect of female-perpetrated IPV for male victims. By not positioning men as helpless or as victims, their rights and privileges in relation to care or professional assistance are potentially limited. The implications therefore, of gendered views can be particularly problematic given the negative effect of IPV upon male victims' physical and emotional wellbeing (Hogan, 2016; Scarduzio et al., 2017). In this instance, not only was female IPV "brushed under the carpet", but so too was male victimisation.

In continuing to explore possible explanations for female-perpetrated IPV, many of the students constructed women's aggression as something that occurs in response to provocation. The students drew on a feminist, progressive discourse in order to frame female aggression as behaviour that can be legitimised within the context of self-protection (Swan and Snow, 2006) and also in relation to identity development. For example, when asked about why women might commit IPV one student reflected:

How they were raised as well (.) even if they were raised in a family where the dad is aggressive towards the mum it's what you're seeing and then you think well I don't wanna be that woman so you'd try and turn it around and you try to be the one in control instead. 
In this instance, the student reasoned female IPV as perhaps a way of resisting taking on traditional gender roles, resisting positions of victim and taking back control. Indeed, the woman discussed in the above scenario was not constructed as violent; rather her aggression was constructed as a way of developing alternative identities that attempt to "turn it around". This supports previously held notions of female-perpetrated violence as being understandable within the context of oppression (Sjoberg, 2010). Thus, it may suggest that there is still a strong tendency to resist positioning women as the sole perpetrator. This may have implications, in that such positioning affords entitlement and legitimacy when considering female violence committed towards male partners.

The current research provides insights into the potential functionality of dominant social constructions around gendered behaviours such as IPV. This early exploratory research has also offered some important understandings into how students aiming to enter the forensic profession construct gender roles, which reflect a gendered stereotypical perspective of women as victims rather than perpetrators. Perhaps more importantly, in their attempts to minimise female-perpetrated IPV, it was evident that this type of violence did not appear to sit comfortably with this group of postgraduate students.

The findings raised important questions in relation to the maintenance of gendered constructions and stereotypes (Binder and McNeil, 1990; Scarduzio et al., 2017) and the implications for forensic practice. The analysis indicated that female-perpetrated IPV was constructed as non-threatening, something not to be taken seriously. Students drew upon biological, gendered, emotional and feminist discourses to position women as vulnerable to harm, as victims, and as non-aggressive. Based on student reporting, female-perpetrated IPV occurred due to emotional instability, provocation, self-defence and as a means of preventing victimisation. We would suggest, therefore, that these constructions functioned to justify female-perpetrated IPV, minimise negative outcomes and reduce accountability.

In considering the implications of the findings for forensic practice, it is argued that social constructions of gender may be one explanation for the inconsistencies observed in terms of bias within forensic assessments. This is highlighted previously in relation to the influence of gender upon assessments of risk and need (Skeem et al., 2005). Pre-existing gendered views of masculinity and femininity can make it challenging for people to accept female-perpetrated IPV and male victimisation, which in turn can influence their interpretation of these situations (Scarduzio et al., 2017). Indeed, the findings of the current research raise important questions in relation to forensic training programmes and the extent to which academic aspects of the training route are sufficient in challenging these constructions. In terms of the implications for practice-based work, understandably there is an expectation to remain gender neutral and objective. The extent to which this is possible, however, is questionable; particularly as the current research shows that gendered constructions were not critically discussed amongst the group of students in the focus group. This supports earlier research, which also found that despite the absence of explicit exploration of gendered issues, people often make inferences and develop their own interpretations of information pertaining to female-perpetrated violence (Scarduzio et al., 2017). This suggests that gendered stereotypes are embedded within narratives surrounding IPV.

Our findings have raised further questions about where, if at all, social constructions are acknowledged and addressed in forensic training. One possibility is that exposure to practice-based work may challenge existing constructions. This could be further enhanced through academic training routes, which could promote awareness of the dominant discourses people draw on in relation to gender and the positioning of female perpetrators of IPV and male victims, and how this plays out in practice.

Forensic psychologists also work with victims as well as perpetrators. The current research highlights how gendered constructions may contribute to the difficulties male victims experience in terms of accessing help. It also highlights the importance of increasing awareness regarding social constructions of gender in ensuring that male victims are cared for and offered appropriate interventions.

There were, however, some limitations to the current research and in particular the participant base could be considered too narrow. Moreover, the participants and primary researcher were all 
female, factors which could have influenced the data and analysis. That said, the aim was not to claim generalisability, particularly as within qualitative research, transferability of learning can still be achieved. Despite the small sample, interesting questions have been raised, which can inform future research where a broader sample that includes different levels of forensic practice experience may provide further insights into gender constructions of IPV. It is also important to point out that this study explored constructions of female-perpetrated IPV within heterosexual relationships. However, there may clearly be other constructions and dominant discourses that surround gender and identity within different types of relationships.

\section{Implications for forensic practice}

- Gendered constructions may be one explanation for the inconsistencies observed within assessments of risk and need in female perpetrators of IPV and male victims.

- The current research raises important questions regarding the extent to which academic training routes identify and challenge constructions of gender.

- Increased awareness is needed amongst those entering forensic training in regard to social constructions of gender and should be incorporated in training routes.

\section{References}

Archer, J. (2000), "Sex differences in aggression between heterosexual partners: a meta-analytical review", Psychological Bulletin, Vol. 136 No. 5, pp. 651-80.

Archer, J. (2006), "Cross cultural difference in physical aggression between partners: a social-role analysis", A Social Psychological Review, Vol. 10 No. 2, pp. 133-53.

Ashley, A. (2008), "Media representations of violent women: exploring stock stereotypes and the denial of agency", unpublished thesis, University of Portsmouth, Portsmouth.

Bem, S. (1993), The Lenses of Gender: Transforming the Debate on Sexual Inequality, Yale University Press, New Haven, CT.

Berrington, E. and Honkatukia, P. (2002), "An evil monster and a poor thing: female violence in the media", Journal of Scandinavian Studies in Criminology and Crime Prevention, Vol. 3 No. 1, pp. 50-72.

Binder, R. and McNeil, D. (1990), "The relationship of gender to violent behaviour in acutely disturbed psychiatric patients”, Journal of Clinical Psychiatry, Vol. 51 No. 3, pp. 110-14.

Butler, J. (1990), Gender Trouble: Feminism and the Subversion of Identity, Routledge, New York, NY.

Carlyle, K., Scarduzio, J. and Slater, M. (2014), "Media portrayals of female perpetrators of intimate partner violence", Journal of Interpersonal Violence, Vol. 29 No. 3, pp. 2394-417, doi: 10.1177/0886260513520231.

Connell, R. (2002), Gender, Polity Press, Cambridge.

Connell, R. and Messerschmidt, J. (2005), "Hegemonic masculinity: re-thinking the concept", Gender and Society, Vol. 19 No. 6, pp. 829-59.

Coontz, P., Lidz, C. and Mulvey, E. (1994), "Gender and the assessment of dangerousness in the psychiatric emergency room”, International Journal of Law and Psychiatry, Vol. 17 No. 4, pp. 369-76.

Cortoni, F., Babchinshin, K. and Rat, C. (2017), "The proportion of sexual offenders who are female is higher than thoughts", Criminal Justice and Behaviour, Vol. 44 No. 2, pp. 145-62.

Davies, B. and Harré, R. (1990), "Positioning: the discursive productions of selves", Journal for the Theory of Social Behaviour, Vol. 20 No. 1, pp. 43-63.

Desmarais, S., Reeves, K., Nicholls, T., Telford, R. and Fiebert, M. (2012), "Prevalence of physical violence in intimate relationships: part 1. Rates of male and female victimization”, Partner Abuse, Vol. 3 No. 2, pp. 140-69.

Dobash, R. and Dobash, R. (1979), Violence Against Wives, The Free Press, New York, NY.

Dobash, R. and Dobash, R. (2004), "Women's violence to men in intimate relationships; working on a puzzle", British Journal of Criminology, Vol. 44 No. 3, pp. 324-49. 
Douglas, K.S., Hart, S.D., Webster, C.D. and Belfrage, H. (2013), HCR-20V3: Assessing Risk of Violence - User Guide, Mental Health, Law, and Policy Institute, Simon Fraser University, Burnaby.

Dutton, D. and White, K. (2013), "Male victims of domestic violence", New Male Studies: An International Journal, Vol. 2 No. 1, pp. 5-17.

Elbogen, E., Williams, A., Kim, D., Tomkins, A. and Scalora, M. (2001), "Gender and perceptions of dangerousness in civil psychiatric patients", Legal and Criminological Psychology, Vol. 6 No. 2, pp. 215-28.

Elmquist, J., Wolford-Clevenger, C., Zapor, H., Febres, J., Sharey, R., Hamel, J. and Stuart, G. (2016), "A gender comparison of motivations for physical dating violence among college students", Journal of Interpersonal Violence, Vol. 31 No. 1, pp. 186-203, doi: 10.1177/0886260514555130.

Graham-Kevan, N. and Archer, J. (2009), "Control tactics and partner violence in heterosexual relationships", Evolution and Human Behaviour, Vol. 30 No. 6, pp. 445-52.

Graham-Kevan, N. and Ashton Wigman, S. (2009), "Treatment approaches for interpersonal violence: domestic violence and stalking", in Ireland, J., Ireland, C. and Birch, P. (Eds), Violent and Sexual Offenders: Assessment and Treatment, Willan Publishing, Devon, pp. 198-235.

Hamby, S. and Jackson, A. (2010), "Size does matter: the effects gender on perceptions of dating violence", Sex Roles, Vol. 63 Nos 5-6, pp. 324-31, doi: 10.1007\%2Fs11/9901098160.

Harré, R. and Moghaddam, F. (2003), The Self and Others: Positioning Individuals and Groups in Personal, Political, and Cultural Contexts, Praeger, Westport, CT.

Harre, R. and van Langenhove, L. (1999), Positioning Theory, Blackwell Publishers, Oxford.

Hearn, J. (2013), "The sociological significance of domestic violence: tensions, paradoxes and implications", Current Sociology, Vol. 61 No. 2, pp. 152-70.

Heyman, G. and Giles, J. (2006), "Gender and psychological essentialism”, Enfance, Vol. 58 No. 3, pp. 293-310.

Hines, D. and Douglas, E. (2010), "Intimate terrorism by women towards men: does it exist?", Journal of Agaression, Conflict, and Peace Research, Vol. 2 No. 3, pp. 36-56.

Hogan, K. (2016), Men's Experiences of Female-Perpetrated Intimate Partner Violence: A Qualitative Exploration, DCounsPsych, University of the West of England, Bristol, available at: http://eprints.uwe.ac.uk/2 8618 (accessed 4 July 2016).

Home Office (2013), "Domestic abuse: guidance and support for the armed forces community, domestic violence and law and the justice system", available at: www.gov.uk/guidance/domestic-violence-and-abuse (accessed 22 April 2016).

Kropp, P.R., Hart, S.D. and Belfrage, H. (2005), "Brief spousal assault form for the evaluation of risk (B-SAFER)", User Manual, Proactive Resolutions, Vancouver.

Kruttschnitt, C., Gartner, R. and Hussemann, J. (2008), "Female Violent offender; moral panics or more serious offenders?", The Australian and New Zealand Journal of Criminologv, Vol. 41 No. 1, pp. 9-35.

Laroche, D. (2005), Aspects of the Context and Consequences of Domestic Violence - Situational Couple Violence and Intimate Terrorism in Canada in 1999, Government of Quebec, Quebec City.

Leisring, P. (2013), "Physical and emotional abuse in romantic relationships: motivation for perpetration among college women", Journal of Interpersonal Violence, Vol. 28 No. 7, pp. 1437-54, doi: 10.1177/ 0886260512468236

Litosseliti, L. (2007), Using Focus Groups in Research, Continuum, London.

Lorber, J. (1994), “'Night to his day'. The social construction of gender”, in Lorber, J. (Ed.), Paradoxes of Gender, pp. 13-36.

Lorber, J. (2010), Gender Inequality: Feminist Theories and Politics, 4th ed., Oxford University Press, New York, NY.

McNeil, D. and Binder, R. (1995), "Correlates of accuracy in the assessment of psychiatric inpatients' risk of violence”, American Journal of Psychiatry, Vol. 152 No. 6, pp. 901-06.

McNulty, J.K. and Hellmuth, J.C. (2008), "Emotion regulation and intimate partner violence in newlyweds", Journal of Family Psychology, Vol. 22 No. 5, pp. 794-7.

Noh, M., Lee, M. and Feltey, K. (2010), "Mad, bad, or reasonable? Newspaper portrayals of the battered woman who kills", Gender Issues, Vol. 27 Nos 3-4, pp. 110-30. 
Office for National Statistics (2015), Intimate Personal Violence and Partner Abuse, The National archives, London, available at: http://webarchive.nationalarchives.gov.uk/20160105160709/http://www.ons.gov.uk/ ons/dcp171776_394500.pdf (accessed 1 December 2015).

Oyserman, D., Elmore, K. and Smith, G. (2012), "Self, self-concept, and identity", in Leary, M. and Tangney, J. (Eds), Handbook of Self and Identity, 2nd ed., Guilford Press, New York, NY, pp. 69-104.

Parker, I. (2005), Qualitative Psychology: Introducing Radical Research, Open University Press, Maidenhead.

Pence, E. and Paymar, M. (1993), Education Groups for Men Who Batter. The Duluth Model, Springer, New York, NY.

Povey, D., Coleman, K., Kaiza, P. and Roe, S. (2009), "Homicides, firearm offences and intimate violence 2007/08 (supplementary volume 2 to crime in England and Wales 2007/2008)", Home Office Statistical Bulletin 02/09, Home Office, London, available at: www.homeoffice.gov.uk/rds/pdfs09/hosb0209.pdf (accessed 22 April 2016).

Scarduzio, J., Carlyle, K., Harris, K. and Savage, M. (2017), “'Maybe she was provoked'. Exploring gender stereotypes and female perpetrators for intimate partner violence", Violence Against Women, Vol. 23 No. 1, pp. 1-25, doi: 10.1177/10778012116636240.

Schippers, M. (2007), "Recovering the feminine other: masculinity, femininity and gender hegemony", Theory and Society, Vol. 36 No. 1, pp. 85-102.

Schrock, D. and Padavic, I. (2007), "Negotiating hegemonic masculinity in a batterer intervention program", Gender \& Society, Vol. 21 No. 5, pp. 625-49.

Simmons, C.A., Lehmann, P. and Cobb, N. (2008), "A comparison of women versus men charged with intimate partner violence: general risk factors, attitudes regarding using violence, and readiness to change", Violence and Victims, Vol. 23 No. 5, pp. 571-85.

Sjoberg, L. (2010), "Women fighters and the 'beautiful soul' narrative", International Review of the Red Cross, Vol. 92 No. 877, pp. 53-68.

Sjoberg, L. and Gentry, C. (2008), "Reduced to bad sex: narratives of violent women from the bible to the war on terror”, International Relations, Vol. 22 No. 1, pp. 5-23.

Skeem, J., Scubert, C., Stowman, S., Beeson, S., Mulvey, E., Gardner, W. and Lidz, C. (2005), "Gender and risk assessment accuracy: underestimating women's violence potential”, Law and Human Behaviour, Vol. 29 No. 2, pp. 173-86.

Sorenson, S.B. and Taylor, C.A. (2005), "Female aggression toward male intimate partners: an examination of social norms in a community-based sample", Psychology of Women Quarterly, Vol. 29 No. 1, pp. 78-96.

Steward, L., Gabora, N., Allegri, N. and Slavin-Steward, M. (2014), "Profile of female perpetrators of intimate partner violence in an offender population: implications for treatment", Partner Abuse, Vol. 5 No. 2, pp. 168-88.

Swan, S. and Snow, D. (2006), "The development of a theory of women's use of violence in intimate relationships", Violence Against Women, Vol. 12 No. 11, pp. 1026-45.

Thornton, A., Graham-Kevan, N. and Archer, J. (2016), "Intimate partner violence: are the risk factors the similar for men and women, and similar to other types of offending?", Aggressive Behaviour, Vol. 42 No. 4, pp. 404-12.

Tremblay, R., Hartup, W. and Archer, J. (2005), The Developmental Origins of Aggression, Guildford Press, New York, NY.

Tsui, V. (2014), "Male victims of intimate partner abuse: use and helpfulness of services", Social Work, Vol. 59 No. 2, pp. 121-30.

Ulmer, J. and Kramer, H.J. (1996), "Court communities under sentencing guidelines: dilemmas of formal rationality and sentencing disparity”, Criminology, Vol. 34 No. 3, pp. 383-408.

van Langenhove, L. and Harré, R. (1999), "Introducing positioning theory", in Harré, R. and van Langenhove, L. (Eds), Positioning Theory, Blackwell, Oxford, pp. 14-31.

Whitaker, M. (2014), "Motivational attributes about intimate partner violence among male and female perpetrators", Journal of Interpersonal Violence, Vol. 29 No. 3, pp. 517-35, doi: 10.1177/ 0886260513505211. 
Williams, J., Ghandour, R. and Kub, J. (2008), "Female perpetration of violence in heterosexual intimate relationships adolescence through adulthood", Trauma Violent Abuse, Vol. 9 No. 4, pp. 227-49.

Willig, C. (2013), Introducing Qualitative Research in Psychology, 3rd ed., Open University Press, Berkshire.

\section{Further reading}

Adams, S. (1996), "Women returners and fractured identities", in Charles, N. and Hughes-Freeland, F. (Eds), Practicing Feminism: Identity Difference Power, Routledge, London, pp. 202-22.

Boonzaier, F. and de la Rey, C. (2004), "Woman abuse: the construction of gender in women and men's narratives of violence", South African Journal of Psychologv, Vol. 34 No. 3, pp. 443-63.

Brannon, R. and David, D. (1976), The Forty-Nine Percent Majority: The Male Sex Role, Addison-Wesley Publishing Company, Reading.

Brown, G.A. (2004), "Gender as a factor in the response of the law-enforcement system to violence against partners", Sexuality and Culture, Vol. 8 Nos 3-4, pp. 3-139.

Burkitt, I. (2008), Social Selves. Theories of Self and Society, 2nd ed., Sage, London.

Henning, K. and Renauer, B. (2005), "Prosecution of women arrested for domestic violence: are they treated more leniently than men?", Violence and Victims, Vol. 20 No. 3, pp. 361-76.

Hester, M. (2009), Who Does What to Whom? Gender and Domestic Violence Perpetrators, University of Bristol in association with the Northern Rock Foundation, Bristol.

Lidz, C., Mulvey, E. and Gardner, W. (1993), "The accuracy of prediction of violence to others", Journal of American Medical Association, Vol. 269 No. 8, pp. 1007-11.

McHugh, M., Livington, N. and Ford, A. (2005), "A postmodern approach to women's use of violence: developing multiple and complex conceptualisations", Psychologv of Women Quarterly, Vol. 29 No. 3, pp. 323-36, doi: 10.111/j1471640220050022.

Moore, H. (1994), A Passion for Difference: Essays in Anthropology and Gender, Indiana University Press, Bloomington, IN.

Neal, A. and Edwards, K. (2015), "Perpetrators and victims attributes for intimate partner violence: a critical review of the literature", Trauma, Violence and Abuse, Vol. 18 No. 3, pp. 1-29, doi: 10.1177/ 1524838015603551.

Owens, L., Shute, R. and Slee, P. (2000a), "Guess what I just heard! Indirect aggression among teenage girls in Australia", Aggressive Behaviour, Vol. 26 No. 1, pp. 67-83.

Owens, L., Shute, R. and Slee, P. (2000b), “I'm in and you're out. Explanations for teenage girls' indirect aggression”, Psychologv, Evolution, and Gender, Vol. 2 No. 1, pp. 19-46.

Peralta, R., Tuttle, L. and Steele, J. (2010), "At the intersection of interpersonal violence, masculinity and alcohol use: the experiences of heterosexual male perpetrators of intimate partner", Violence Against Women, Vol. 16 No. 4, pp. 387-409.

Straus, M. and Gozjolko, K. (2014), “ 'Intimate terrorism' and gender differences in injury of dating partner by male and female university students”, Journal of Family Violence, Vol. 29 No. 1, pp. 51-65, doi: 10.1007/ 51089601395607.

Ussher, J. (1997), Body Talk: The Material and Discursive Regulation of Sexuality, Madness and Reproduction, Routledge, London.

Vandellow, J. and Cohen, D. (2003), "Male honor and female fidelity: implicit cultural scripts that perpetuate domestic violence", Journal of Personality and Social Psychologv, Vol. 84 No. 5, pp. 997-1010.

\section{Corresponding author}

Jenna Walker can be contacted at: Jenna.Walker@serco.com

For instructions on how to order reprints of this article, please visit our website:

www.emeraldgrouppublishing.com/licensing/reprints.htm

Or contact us for further details: permissions@emeraldinsight.com 